\title{
Diurnal and seasonal carbon balance of four tropical tree species differing in successional status
}

\author{
Souza, GM. ${ }^{\mathrm{a}}$, Ribeiro, $R V^{\mathrm{b}}$, Sato, AM. ${ }^{\mathrm{a}}$, Oliveira, $M S{ }^{\mathrm{a}}$ \\ aLaboratório de Ecofisiologia Vegetal, Universidade do Oeste Paulista - UNOESTE, \\ Rod. Raposo Tavares, km 572, CEP 19067-175, Presidente Prudente, SP, Brazil

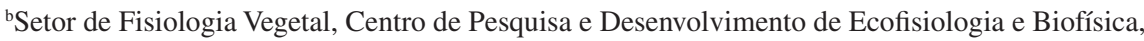 \\ Instituto Agronômico - IAC, CP 28, CEP 13012-970, Campinas, SP, Brazil \\ *e-mail: gustavo@unoeste.br
}

Received April 4, 2007 - Accepted August 13, 2007 - Distributed November 30, 2008

(With 9 figures)

\begin{abstract}
This study addressed some questions about how a suitable leaf carbon balance can be attained for different functional groups of tropical tree species under contrasting forest light environments. The study was carried out in a fragment of semi-deciduous seasonal forest in Narandiba county, São Paulo Estate, Brazil. 10-month-old seedlings of four tropical tree species, Bauhinia forficata Link (Caesalpinioideae) and Guazuma ulmifolia Lam. (Sterculiaceae) as light-demanding pioneer species, and Hymenaea courbaril L. (Caesalpinioideae) and Esenbeckia leiocarpa Engl. (Rutaceae) as late successional species, were grown under gap and understorey conditions. Diurnal courses of net photosynthesis (Pn) and transpiration were recorded with an open system portable infrared gas analyzer in two different seasons. Dark respiration and photorespiration were also evaluated in the same leaves used for Pn measurements after dark adaptation. Our results showed that diurnal-integrated dark respiration (Rdi) of late successional species were similar to pioneer species. On the other hand, photorespiration rates were often higher in pioneer than in late successional species in the gap. However, the relative contribution of these parameters to leaf carbon balance was similar in all species in both environmental conditions. Considering diurnal-integrated values, gross photosynthesis (Pgi) was dramatically higher in gap than in understorey, regardless of species. In both evaluated months, there were no differences among species of different functional groups under shade conditions. The same was observed in May (dry season) under gap conditions. In such light environment, pioneers were distinguished from late successional species in November (wet season), showing that ecophysiological performance can have a straightforward relation to seasonality.
\end{abstract}

Keywords: functional groups, leaf gas exchange, net photosynthesis, photorespiration, seasonality.

\section{Balanço de carbono diurno e sazonal de quatro espécies tropicais arbóreas de diferentes grupos sucessionais}

\section{Resumo}

Este estudo considerou algumas questões sobre como um adequado balanço de carbono foliar pode ser obtido por diferentes grupos funcionais de espécies tropicais arbóreas sob contrastantes ambientes luminosos em uma floresta. $\mathrm{O}$ estudo foi realizado em um fragmento de floresta estacional semidecidual localizada no município de Narandiba, Estado de São Paulo. Plântulas com dez meses de idade de quatro espécies, Bauhinia forficata Link (Caesalpinioideae) e Guazuma ulmifolia Lam. (Sterculiaceae) como espécies pioneiras, e Hymenaea courbaril L. (Caesalpinioideae) e Esenbeckia leiocarpa Engl. (Rutaceae) como espécies secundárias, cresceram em um ambiente de clareira e um de sub-bosque durante nove meses. Cursos diários da fotossíntese líquida (Pn) e transpiração foram medidos com um medidor portátil de trocas gasosas por infravermelho nas estações seca e chuvosa. A respiração no escuro (Rd) e a fotorrespiração $(\mathrm{Pr})$ foram também avaliadas nas mesmas folhas utilizadas para as medidas de Pn após um período de adaptação ao escuro. Nossos resultados mostraram que a respiração integrada ao longo do dia foi similar entre as espécies dos dois grupos sucessionais. Por outro lado, a fotorrespiração das espécies pioneiras foi freqüentemente maior do que nas espécies secundárias em condições de clareira. Todavia, a contribuição relativa de Pr no balanço de carbono nas folhas foi similar em todas as espécies em ambos os ambientes. Independentemente da espécie, a fotossíntese bruta, considerando os valores integrados ao longo do dia, foi significativamente maior na clareira que no sub-bosque. Nas duas épocas avaliadas, não foram observadas diferenças significativas em nenhum dos parâmetros avaliados entre as espécies crescidas no ambiente de sub-bosque. O mesmo foi observado no mês de maio sob condições de clareira. No mês de novembro, as espécies pioneiras apresentaram uma performance ecofisiológica significativamente distinta das espécies secundárias no ambiente de clareira, indicando uma relação direta entre a sazonalidade climática e o padrão de respostas ecofisiológico de algumas espécies crescendo em ambiente aberto.

Palavras-chave: fotossíntese líquida, fotorrespiração, grupos funcionais, trocas gasosas, sazonalidade. 


\section{Introduction}

Tropical forest environments often show a wide range of light availability in both spatial and temporal scales. While gaps of different sizes show different light conditions during day time (Martins and Rodrigues, 2002), with photosynthetic photon flux densities $(Q)$ ranging from 25 in early morning to $2300 \mu \mathrm{mol} . \mathrm{m}^{-2} / \mathrm{s}$ around midday, understorey light environments are characterized by low diffuse irradiance, punctuated by sunflecks from a few seconds to minutes (Bazzaz and Picket, 1980; Chazdon et al., 1996). Therefore, tropical forest species often experience substantial diurnal and seasonal light variation, as well as other environmental factors such as water availability (Eamus, 1999).

In order to grow in low light environments such as the forest understorey, where plants have low carbon gain (Chazdon et al., 1996; Strauss-Debenedetti and Bazzaz, 1996), plants must minimize carbon loss reducing both respiration and tissues construction cost (Givnish, 1988), attaining a positive leaf carbon balance. This hypothesis suggests that species acclimate to low light down-regulating respiration which would reduce carbon losses (Reich et al., 1998).

Respiration, physiologically defined as a non-photorespiratory $\mathrm{CO}_{2}$ release (Amthor, 2000), is higher in gap environments than in forest understorey. In general, pioneer species show higher leaf respiration than late successional ones (Bazzaz and Pickett. 1980; Chazdon et al., 1996). According to Fredeen and Field (1991), Piper species normally found in large gaps or clearings, had approximately twice the rate of dark respiration as species found predominantly in understorey sites. The same was observed by Ramos and Grace (1990) for pioneer and intermediary species, however dark respiration of climax species was 8-fold higher in gap than in understorey. In light limited conditions, late successional species respond rapidly to light flecks maintaining respiratory losses at a minimum (Strauss-Debenedetti and Bazzaz, 1996).

Respiration rates may also be affected by plant developmental stage, temperature, nitrogen content (Amthor, 2000; Lee et al., 2005) and seasonal environmental changes, such as water availability (Lee et al., 2005; Miranda et al., 2005). However, there is little available data addressing this wide spectrum of possibilities that affect carbon balance in tropical forest vegetation (Wright et al., 2005).

The objective of this work was to study the influence of distinct light environments in situ, in dry and wet seasons, on leaf carbon balance of four tropical tree species with different ecological traits. We address the following hypotheses: 1) saplings in understorey conditions show reduced diurnal respiration rates regardless of successional status; 2) diurnal leaf carbon balance responds to seasonal variation; 3) saplings growing in high-light environments show higher net $\mathrm{CO}_{2}$ assimilation, respi- ration and photorespiration rates than those growing in the shade.

\section{Material and Methods}

\subsection{Species and experimental conditions}

This study was carried out in a fragment of semideciduous seasonal forest of 5.5 ha located in Narandiba county, Brazil (22 24 ' $24^{\prime \prime}$ S and 51 $31^{\circ} 29^{\prime}$ ' W, altitude of $354 \mathrm{~m}$ ). The size of the forest gap was $34.5 \mathrm{~m}^{2}$, corresponding to a small gap with canopy openness around 10\% (Martins and Rodrigues, 2002). The climate is Aw type, defined as tropical with wet summer and dry winter, according to the Köppen classification. Regional mean annual temperature, rainfall and annual potential evaporative demand are $23{ }^{\circ} \mathrm{C}, 1,223 \mathrm{~mm}$ and $1,170 \mathrm{~mm}$, in that order (Embrapa, 2003).

In this study we evaluated four well known Brazilian species from different successional groups, Bauhinia forficata Link (Caesalpinioideae) and Guazuma ulmifolia Lam. (Sterculiaceae) as light-demanding pioneer species, and Hymenaea courbaril L. (Caesalpinioideae) and Esenbeckia leiocarpa Engl. (Rutaceae) as shade-adapted late successional species (Lorenzi, 1992). These species were germinated and cultivated in $5 \mathrm{~L}$ pots filled with organic substrate under nursery conditions, 50\% full sunlight. Ten 10-month-old saplings of each species were planted under field conditions, in an experimental random design, with a minimum distance of $1.0 \mathrm{~m}$ from each other, in contrasting natural light environments: a gap and an understorey site. Plants were grown under such conditions from March to November 2005.

Physiological measurements were carried out in May (autumn, dry season) and November (late spring, wet season) 2005. Environmental conditions were remarkably different in the evaluated seasons. In May, mean air temperature was $22.7{ }^{\circ} \mathrm{C}$ and rainfall was $34 \mathrm{~mm}$. The accumulated water deficiency in soil was $54 \mathrm{~mm}$, as indicated by the climatic water balance calculated according to Thornthwaite and Matter (1955). On the other hand, November had mean air temperature of $25.9{ }^{\circ} \mathrm{C}$, rainfall of $116 \mathrm{~mm}$, and there was no soil water deficiency, as given by the null value of climatic water balance. In understorey, photosynthetic photon flux density (PPFD) was practically unchanged throughout the day in both evaluations, c. $25 \mu \mathrm{mol}$ photons. $\mathrm{m}^{-2} / \mathrm{s}$ (Figure 1a), with diurnal-integrated PPFD ranging from $0.37 \mathrm{~mol}$ photons. $\mathrm{m}^{-2}$ /day in May to 0.47 mol photons. $\mathrm{m}^{-2}$ /day in November. Probably, total irradiance in understorey was underestimated since sunflecks were not recorded. However, leaves evaluated in understorey were not exposed to sunflecks during gas exchange measurements. In the gap, significant variations in irradiance were recorded throughout the daytime. The highest PPFD value was around $2000 \mu \mathrm{mol}$.photons. $\mathrm{m}^{-2} / \mathrm{s}$ at 12:00 PM (Figure 1a). Diurnal-integrated PPFD in May was $27.9 \mathrm{~mol}$ photons. $\mathrm{m}^{-2} / \mathrm{d}$, while in November it 
was $39.1 \mathrm{~mol}$ photons. $\mathrm{m}^{-2} / \mathrm{d}$. Accordingly, the highest air temperature and air vapor pressure deficit $\left(\mathrm{VPD}_{\text {air }}\right)$ values were also found in gap conditions, mainly between 10:00 AM and 02:00 PM. Maximum air temperature and $\mathrm{VPD}_{\text {ir }}$ in May reached $31{ }^{\circ} \mathrm{C}$ and $1.8 \mathrm{kPa}$, respectively, while in November those variables reached $36{ }^{\circ} \mathrm{C}$ and $2.2 \mathrm{kPa}$, respectively (Figures $1 \mathrm{~b}, \mathrm{c}$ )
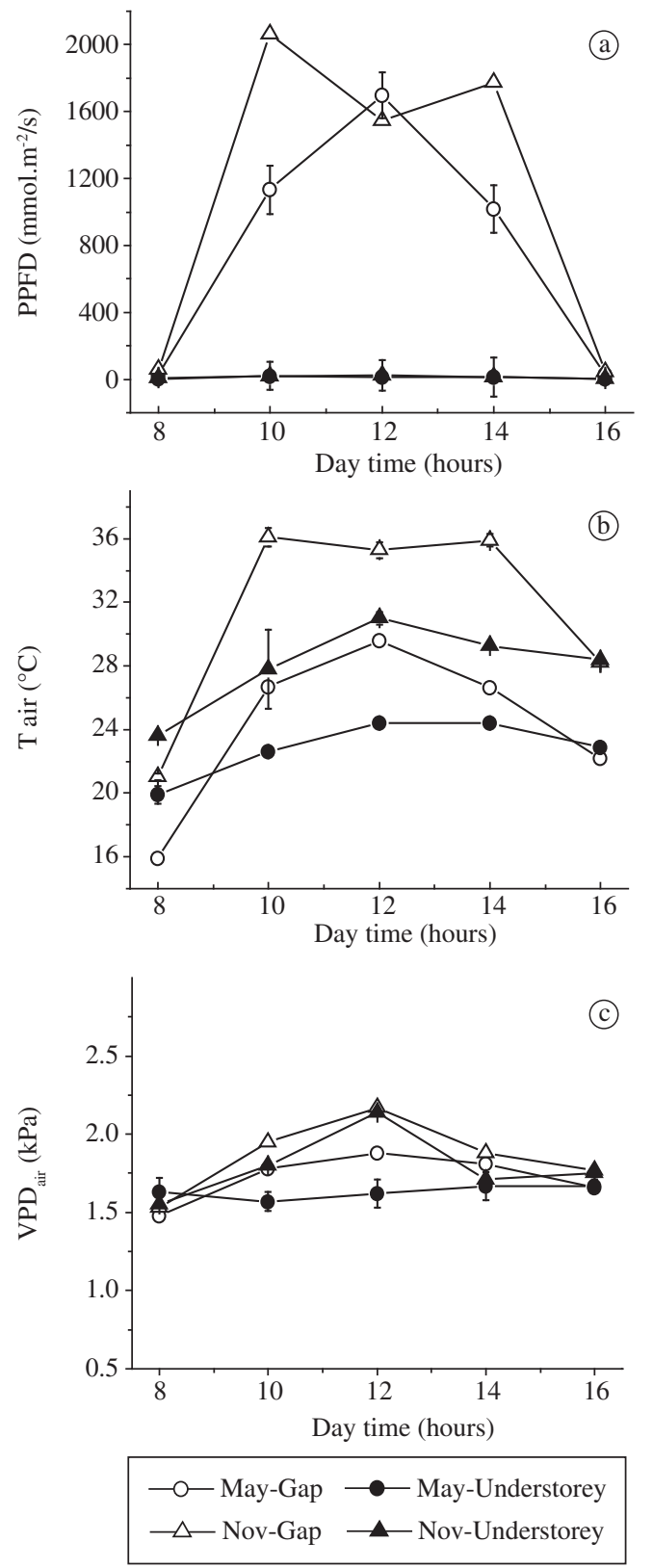

Figure 1. Diurnal courses of photosynthetic photon flux density (PPFD, a) air temperature $\left(\mathrm{T}_{\mathrm{air}}, \mathrm{b}\right)$ and atmospheric vapor pressure deficit $(\mathrm{VPD}, \mathrm{c})$ in a tropical semi-deciduous forest gap (open symbols) and understorey (solid symbols). Measurements were carried out in May (dry season) and in November (wet season) 2005. Symbols are mean values of 12 replicates $( \pm$ s.e. $)$.

\subsection{Physiological measurements}

Gas exchange measurements were carried out from 8:00 to $16: 00$ hours in intervals of two hours in plants grown under gap and understorey conditions. In each environmental condition three plants per species were evaluated. All measurements were recorded in days with no or few clouds, showing very similar climatic conditions (see small standard errors in Figure 1), in one young but fully expanded leaf per plant without herbivory damage, mosses or fungi. Three measurements per leaf were averaged in order to reduce natural variability, increasing data reliability. Net photosynthesis (Pn), stomatal conductance (gs), transpiration rate (E) and intercellular $\mathrm{CO}_{2}$ concentration $(\mathrm{Ci})$ were recorded with an open system portable infrared gas analyzer (model CIRAS-2, PPSystems, UK). The diurnal course of dark respiration $(\mathrm{Rd})$ was recorded in the same leaves used for Pn evaluation, in a different day under similar environmental conditions. Another day was utilized since it would be impossible to carry out in a single day diurnal courses of gas exchanges under light and darkened conditions with a single IRGA. Leaves were darkened inside the CIRAS-2 sample chamber which was covered with a black tissue reducing incident irradiance on the sampled leaf to zero. The measures were recorded when gas exchange reached the steady-state $(\mathrm{CV} \leq 1 \%)$. All gas exchange measurements were carried out under natural environmental conditions (light, air temperature, humidity and atmospheric $\mathrm{CO}_{2}$ concentration of $350 \pm$ $\left.10 \mu \mathrm{mol} . \mathrm{mol}^{-1}\right)$. Photorespiration was estimated according to Sharkey (1988) as follows:

$\mathrm{v}_{0}=(\mathrm{A}+\mathrm{Rd}) /(1 / \Phi-0.5)$

where $\mathrm{v}_{0}$ is the rate of Rubisco (ribulose bi-phosphate oxygenase /carboxylase) oxygenation, $\mathrm{A}$ is the photosynthetic $\mathrm{CO}_{2}$ assimilation, $\mathrm{Rd}$ is the respiration measured under dark conditions, and $\Phi$ is the ratio between carboxilation and oxigenation rates of Rubisco according to Farquhar and von Caemmerer (1982). The oxygenation rate was considered as twice the rate of photorespiration (Sharkey, 1988).

Values of Pn, Rd and Pr obtained during the daily courses were integrated using the following equation, which generated the corresponding values per day (Kikusawa et al., 2004)

$$
I(y)=\int_{0}^{y} f(x) d x
$$

$\mathrm{x}=$ independent variable (time interval in seconds along the daily course $) ; \mathrm{I}(\mathrm{y})=$ integrated $\mathrm{y}$ value; and $\mathrm{f}(\mathrm{x})=$ the dependent variable (Pn, Rd or Pr).

Leaf gross photosynthesis $(\mathrm{Pg}=\mathrm{Pn}+\mathrm{Rd}+\mathrm{Pr})$ was calculated as net $\mathrm{CO}_{2}$ assimilation ( $\mathrm{Pn}$ ) plus carbon losses by respiration $(\mathrm{Rd})$ and photorespiration $(\mathrm{Pr})$ processes (Larcher, 1995). Leaf water potential was measured with a pressure chamber (PMS 1000, PMS Instruments, EUA) at pre-dawn in the same plants used for gas ex- 
change measurements. Plant growth was evaluated taking into account primary and secondary growth measured as plant height and stem diameter, respectively. Those evaluations were done in five plants per species in both gap and understorey conditions in May (dry season) and November (wet season) 2005. Water use efficiency (WUE) was calculated as the integrated net photosynthesis normalized by the integrated transpiration.

\subsection{Data analyses}

After confirming homoscedasticity, data was submitted to the ANOVA procedure $(\mathrm{P}<0.05)$ and an a posteriori Tukey test was performed in order to compare mean values.

A multivariate statistical analysis using principal components (PCA) was also performed taking into account all physiological measurements (gas exchange and growth data) in order to distinguish functional groups in each environmental condition and in both seasons. Broken-stick criterion was used for eigenvector assessment (Peres-Neto et al., 2003). In this study two principal components were considered, pc 1 and pc 2, which were representative of original data variance. PCA is a reliable tool to separate emergent functional groups (Lavorel et al., 1997) and has been used to test functional group hypothesis with woody tropical species considering ecophysiological data such as herein (Prado et al., 2004; Ribeiro et al., 2004 and 2005).

\section{Results}

\subsection{Pre-dawn leaf water potential}

Plant water status evaluated by measurements of pre-dawn leaf water potential $\left(\Psi_{\text {wpd }}\right)$ showed significant $(\mathrm{P}<0.05)$ differences between May and November. However, there were no differences $(\mathrm{P}>0.05)$ in $\Psi_{\text {wpd }}$ values between plants in gap and understorey conditions and among the four tree species evaluated. Mean $\Psi_{\text {wpd }}$ in both environments in all species was around - 1.0 MPa in May and - 0.4 MPa in November. These differences were determined by low water soil content in May, as suggested by the climatic water balance. Nevertheless, these $\Psi_{\text {wpd }}$ values do not indicate severe water deficit for these woody species throughout the year (Souza et al., 2004).

\subsection{Diurnal courses and integrated values of leaf gas exchange}

Diurnal variations in net photosynthesis $(\mathrm{Pn})$ were far higher under gap than in the understorey environment for all species in both seasons (Figure 2). Pioneer species showed higher $(\mathrm{P}<0.05)$ maximum $\mathrm{Pn}$ values $\left(\mathrm{Pn}_{\max }\right)$ than secondary species E. leiocarpa under gap conditions in May (dry season) and November (wet season) (Tables 1 and 2). Non-significant $(\mathrm{P}>0.05)$ differences among species were observed in understorey (Tables 1 and 2). Diurnal-integrated Pn (Pni) trended to be higher in November than in May for all species, remarkably in understorey conditions (Tables 1 and 2). For instance, Pni in E. leiocarpa (late secondary species) and $B$. forficata (pioneer species) grown in understorey was 18.4 and $2.0 \mathrm{mmol} \mathrm{CO}_{2} \cdot \mathrm{m}^{-2} / \mathrm{d}$ in May, respectively, while, Pni in November was around 66 and $51 \mathrm{mmol} \cdot \mathrm{CO}_{2} \cdot \mathrm{m}^{-2} / \mathrm{d}$ in E. leiocarpa and $B$. forficata respectively. In both months Pni values were higher $(\mathrm{P}<0.05)$ in gap than in understorey for all species.

The transpiration rate also exhibited higher variations in gap than in understorey conditions (Figure 3) caused by higher stomatal conductance fluctuations (Figure 4). Diurnal-integrated values of transpiration (Ei) were remarkably higher in November than in May regardless of light environment (Table 1 and 2), because of higher stomatal conductance in that month (Figure 4). These results were consistent with differences in environmental conditions between both months since November showed higher VPD and soil water availability than May (Figure 1), promoting higher Ei. Under gap conditions, pioneer species trended to show higher Ei values than late secondary species, mainly in November (Tables 1 and 2). Late sucessional E. leiocarpa showed lower Ei than pioneer species $(\mathrm{P}<0.05)$. Water use efficiency (WUE) showed different patterns between both months. In May, WUE was consistently higher $(\mathrm{P}<0.05)$ under gap than in understorey for both functional groups (Table 1). On the other hand, in November, WUE was quite similar between gap and understorey regardless of functional group (Table 2). These results may be explained by very low Pni values observed in May in understorey conditions (Table 1), when compared with those observed in November (Table 2). Ei values did not show such remarkable difference between both evaluations (Table 1 and 2).

In May, diurnal course of dark respiration ( $\mathrm{Rd})$, corresponding to mitochondrial respiration (Amthor, 2000), showed similar dynamics among species and between environments (Figure 5). However, integrated $\mathrm{Rd}$ values ( $\mathrm{Rdi}$ ) were about two to three-fold higher in gap than in understorey, regardless of functional group (Table 1). Rdi values observed in November were around three-fold higher than in May under gap and understorey conditions, again independently of successional status (Table 2). Such differences may be explained in part by the high air temperature observed in November, when air temperature reached $36^{\circ} \mathrm{C}$ from 10:00 AM to 02:00 PM in gap (Figure 1b). Respiration is temperature-sensitive, increasing approximately exponentially with temperature (Wright et al., 2005). As observed herein, Rd tends to increase with air temperature, which may account for the high Rd values found in November. Photorespiration (Pr) under gap conditions was higher than in understorey for all species $(\mathrm{P}<0.05)$, mainly from 10:00 AM to 02:00 PM (Figure 6). This fact was related to higher irradiance and air temperature in gap. Diurnal-integrated Pr (Pri) in November was two-fold higher than in May under gap conditions, while Pri in understorey was almost ten-fold higher in November than in May (Table 1 and 

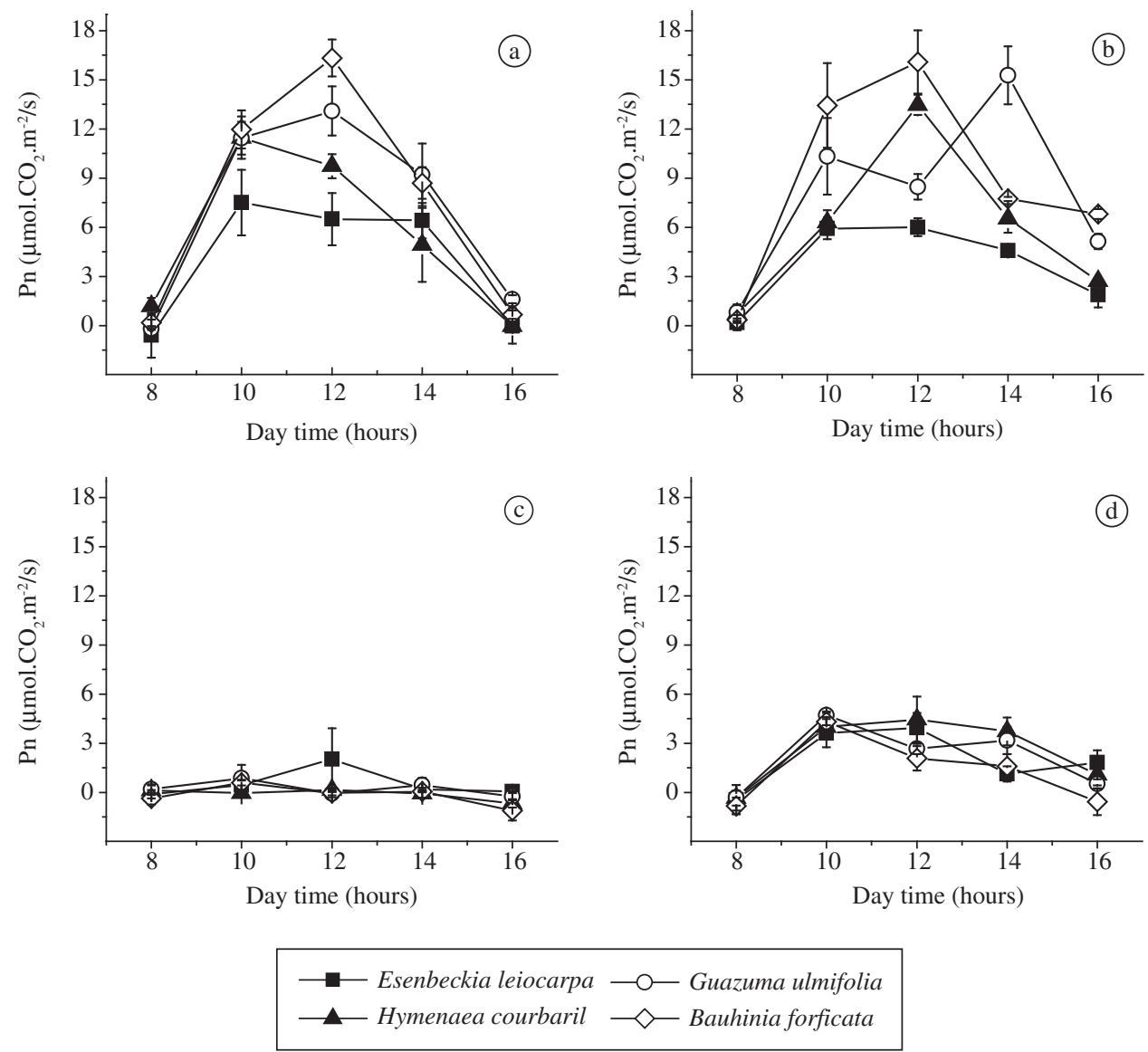

Figure 2. Diurnal courses of net $\mathrm{CO}_{2}$ assimilation (Pn) in pioneer species Bauhinia forficata and Guazuma ulmifolia (open symbols), and secondary species Hymenaea courbaril and Esenbeckia leiocarpa (solid symbols) grown in a tropical semideciduous forest under gap (a,b) and understorey (c,d) conditions. Measurements were taken in May (a,c, dry season, May 2, 2005 ) and in November (b,d, wet season, November 3, 2005) 2005. Symbols are mean values of 3 replicates ( \pm s.e.).

Table 1. Maximum net photosynthesis $\left(\mathrm{Pn}_{\max }\right)$ and diurnal-integrated values of physiological variables of tropical tree species growing under gap (G) and understorey (U) conditions in May (dry season) 2005: net photosynthesis (Pni); dark respiration (Rdi); photorespiration (Pri); gross photosynthesis (Pgi); transpiration (Ei); and water use efficiency (WUEi) of Bauhinia forficata and Guazuma ulmifolia, as pioneer species, and Hymenaea courbaril and Esenbeckia leiocarpa, as secondary species. Plants were grown in a fragment of a Brazilian semi-deciduous seasonal forest. Data were recorded between 8 am and 4 pm (in intervals of 2 hours) in fully expanded leaves. Different capital letters indicate significant difference (Tukey, $\mathrm{P}<0.05$ ) between plants under gap and understorey conditions in each species, while small letters represent significant differences (Tukey, $\mathrm{P}<0.05$ ) among species in each environmental condition.

\begin{tabular}{|c|c|c|c|c|c|c|c|c|}
\hline \multirow[t]{3}{*}{ Species } & \multirow[t]{3}{*}{ Site } & \multicolumn{7}{|c|}{ Physiological parameters } \\
\hline & & \multirow{2}{*}{$\frac{\mathrm{Pn}_{\max }}{\left(\mu \mathrm{mol} \mathrm{CO} \cdot \mathrm{m}^{-2} / \mathrm{s}\right)}$} & Pni & Rdi & Pri & Pgi & \multirow{2}{*}{$\frac{\mathrm{Ei}}{\left(\mathrm{mol} \cdot \mathrm{m}^{-2} / \mathrm{d}\right)}$} & \multirow{2}{*}{$\frac{\text { WUEi }}{\left(\mathrm{mmol.mol}^{-1}\right)}$} \\
\hline & & & & $(\mathbf{m m o l}$ & $\left.\mathbf{m}^{-2} / \mathbf{d}\right)$ & & & \\
\hline \multirow[t]{2}{*}{ E. leiocarpa } & G & $7.50^{\mathrm{Ab}}$ & $144.63^{\mathrm{Ac}}$ & $51.84^{\mathrm{Aa}}$ & $46.54^{\mathrm{Ac}}$ & $243.02^{\mathrm{Ac}}$ & $64.24^{\mathrm{Ab}}$ & $2.26^{\mathrm{Ab}}$ \\
\hline & $\mathrm{U}$ & $2.00^{\mathrm{Ba}}$ & $18.36^{\mathrm{Ba}}$ & $16.08^{\mathrm{Ba}}$ & $4.51^{\mathrm{Ba}}$ & $38.95^{\mathrm{Ba}}$ & $20.45^{\mathrm{Ba}}$ & $0.84^{\mathrm{Ba}}$ \\
\hline \multirow[t]{2}{*}{ H. courbaril } & G & $11.47^{\mathrm{Aa}}$ & $192.24^{\mathrm{Ab}}$ & $52.20^{\mathrm{Aa}}$ & $63.99^{\mathrm{Ab}}$ & $308.43^{\mathrm{Ab}}$ & $63.56^{\mathrm{Ab}}$ & $3.07^{\mathrm{Aab}}$ \\
\hline & $\mathrm{U}$ & $0.13^{\mathrm{Ba}}$ & $0.96^{\mathrm{Ba}}$ & $19.81^{\mathrm{Ba}}$ & $4.58^{\mathrm{Ba}}$ & $25.34^{\mathrm{Ba}}$ & $21.03^{\mathrm{Ba}}$ & $0.05^{\mathrm{Ba}}$ \\
\hline \multirow{2}{*}{ B. forficata } & G & $13.10^{\mathrm{Aa}}$ & $269.40^{\mathrm{Aa}}$ & $60.00^{\mathrm{Aa}}$ & $78.58^{\mathrm{Aa}}$ & $407.98^{\mathrm{Aa}}$ & $78.35^{\mathrm{Aa}}$ & $3.44^{\mathrm{Ab}}$ \\
\hline & $\mathrm{U}$ & $0.83^{\mathrm{Ba}}$ & $2.04^{\mathrm{Ba}}$ & $23.69^{\mathrm{Ba}}$ & $5.66^{\mathrm{Ba}}$ & $31.39^{\mathrm{Ba}}$ & $25.83^{\mathrm{Ba}}$ & $0.07^{\mathrm{Ba}}$ \\
\hline \multirow[t]{2}{*}{ G. ulmifolia } & G & $16.33^{\mathrm{Aa}}$ & $247.92^{\mathrm{Aa}}$ & $38.76^{\mathrm{Bb}}$ & $63.06^{\mathrm{Ab}}$ & $349.74^{\mathrm{Ab}}$ & $69.52^{\mathrm{Aab}}$ & $3.57^{\mathrm{Aa}}$ \\
\hline & $\mathrm{U}$ & $0.57^{\mathrm{Ba}}$ & $9.96^{\mathrm{Ba}}$ & $18.31^{\mathrm{Ba}}$ & $4.81^{\mathrm{Ba}}$ & $33.08^{\mathrm{Ba}}$ & $20.81^{\mathrm{Ba}}$ & $0.52^{\mathrm{Ba}}$ \\
\hline
\end{tabular}


Table 2. Maximum net photosynthesis $\left(\mathrm{Pn}_{\max }\right)$ and diurnal-integrated values of physiological variables of tropical tree species growing under gap (G) and understorey (U) conditions in November 2005 (wet season): net photosynthesis (Pni); dark respiration (Rdi); photorespiration (Pri); gross photosynthesis (Pgi); transpiration (Ei); and water use efficiency (WUEi) of Bauhinia forficata and Guazuma ulmifolia, as pioneer species, and Hymenaea courbaril and Esenbeckia leiocarpa, as secondary species. Plants were grown in a fragment of a Brazilian semi-deciduous seasonal forest. Data were recorded between 8:00 AM and 4:00 PM (in intervals of 2 hours) in fully expanded leaves. Different capital letters indicate significant difference (Tukey, $\mathrm{P}<0.05$ ) between plants under gap and understorey conditions in each species, while small letters represent significant differences (Tukey, $\mathrm{P}<0.05$ ) among species in each environmental condition.

\begin{tabular}{|c|c|c|c|c|c|c|c|c|}
\hline \multirow[t]{3}{*}{ Species } & \multirow[t]{3}{*}{ Site } & \multicolumn{7}{|c|}{ Physiological parameters } \\
\hline & & \multirow{2}{*}{$\frac{\mathrm{Pn}_{\max }}{\left(\mu \mathrm{mol} \mathrm{CO} \mathrm{CO}_{2} \cdot \mathrm{m}^{-2} / \mathrm{s}\right)}$} & Pni & Rdi & Pri & Pgi & \multirow{2}{*}{$\frac{\mathrm{Ei}}{\left(\mathrm{mol} . \mathrm{m}^{-2} / \mathrm{d}\right)}$} & \multirow{2}{*}{$\begin{array}{c}\text { WUEi } \\
\left(\mathrm{mmol} . m o l^{-1}\right) \\
\end{array}$} \\
\hline & & & & (mmol. & $\left.\mathrm{m}^{-2} / \mathbf{d}\right)$ & & & \\
\hline \multirow[t]{2}{*}{ E. leiocarpa } & G & $6.00^{\mathrm{Aa}}$ & $126.00^{\mathrm{Ac}}$ & $129.00^{\mathrm{Aa}}$ & $88.22^{\mathrm{Ac}}$ & $343.34^{\mathrm{Ac}}$ & $128.24^{\mathrm{Ab}}$ & $0.99^{\mathrm{Ac}}$ \\
\hline & $\mathrm{U}$ & $3.90^{\mathrm{Ba}}$ & $66.00^{\mathrm{Ba}}$ & $69.36^{\mathrm{Ba}}$ & $40.97^{\mathrm{Ba}}$ & $176.33^{\mathrm{Ba}}$ & $48.23^{\mathrm{Ba}}$ & $1.44^{\mathrm{Ba}}$ \\
\hline \multirow[t]{2}{*}{ H. courbaril } & G & $13.47^{\mathrm{Ab}}$ & $201.60^{\mathrm{Ab}}$ & $125.16^{\mathrm{Aab}}$ & $111.83^{\mathrm{Ab}}$ & $438.59^{\mathrm{Ab}}$ & $125.43^{\mathrm{Ab}}$ & $1.62^{\mathrm{Aab}}$ \\
\hline & $\mathrm{U}$ & $4.40^{\mathrm{Ba}}$ & $88.68^{\mathrm{Ba}}$ & $66.72^{\mathrm{Ba}}$ & $47.45^{\mathrm{Ba}}$ & $202.85^{\mathrm{Ba}}$ & $49.57^{\mathrm{Ba}}$ & $1.81^{\mathrm{Ba}}$ \\
\hline \multirow[t]{2}{*}{ B. forficata } & G & $15.27^{\mathrm{Ab}}$ & $294.00^{\mathrm{Aa}}$ & 119.28 & $131.27^{\mathrm{Aa}}$ & $544.55^{\mathrm{Aa}}$ & $165.80^{\mathrm{Aa}}$ & $1.81^{\mathrm{Aa}}$ \\
\hline & $\mathrm{U}$ & $4.67^{\mathrm{Ba}}$ & $51.00^{\mathrm{Ba}}$ & $92.88^{\mathrm{Ba}}$ & $41.92^{\mathrm{Ba}}$ & $185.80^{\mathrm{Ba}}$ & $47.29^{\mathrm{Ba}}$ & $1.17^{\mathrm{Ba}}$ \\
\hline \multirow[t]{2}{*}{ G. ulmifolia } & G & $16.10^{\mathrm{Ab}}$ & $266.66^{\text {Aa }}$ & $99.00^{\mathrm{Ac}}$ & $122.47^{\mathrm{Aab}}$ & $488.11^{\mathrm{Aab}}$ & $189.54^{\mathrm{Aa}}$ & $1.42^{\mathrm{Aab}}$ \\
\hline & $\mathrm{U}$ & $4.70^{\mathrm{Ba}}$ & $75.24^{\mathrm{Ba}}$ & $81.36^{\mathrm{Ba}}$ & $45.73^{\mathrm{Ba}}$ & $202.33^{\mathrm{Ba}}$ & $48.41^{\mathrm{Ba}}$ & $1.58^{\mathrm{Ba}}$ \\
\hline
\end{tabular}
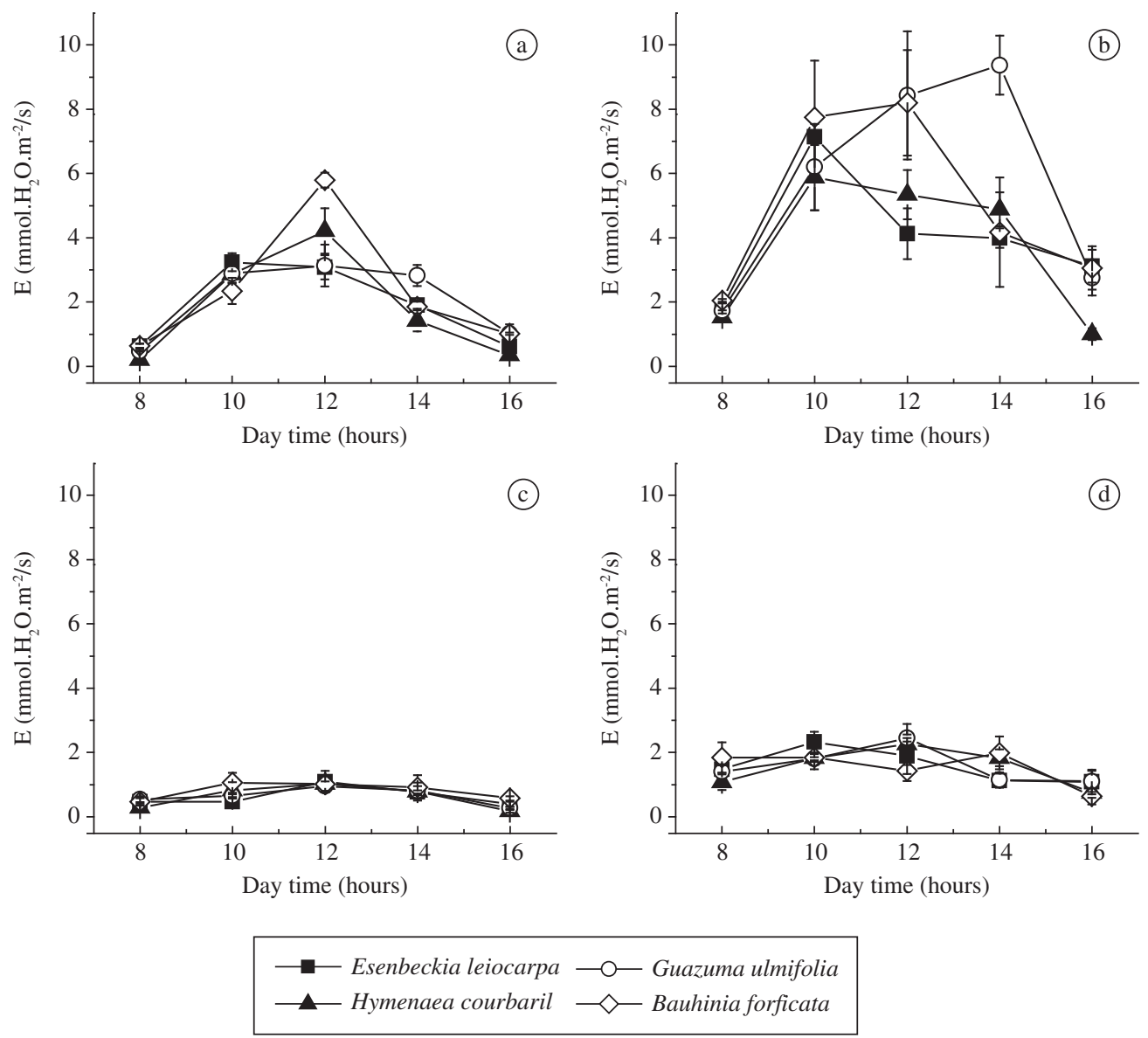

Figure 3. Diurnal courses of transpiration (E) in pioneer species Bauhinia forficata and Guazuma ulmifolia (open symbols) and secondary species Hymenaea courbaril and Esenbeckia leiocarpa (solid symbols) grown in a tropical semi-deciduous forest gap (a, b) and understorey (c, d) conditions. Measurements were taken in May (a, c, dry season, May 2, 2005) and November (b, d, wet season, November 3, 2005) 2005. Symbols are mean values of 3 replicates ( \pm s.e.). 

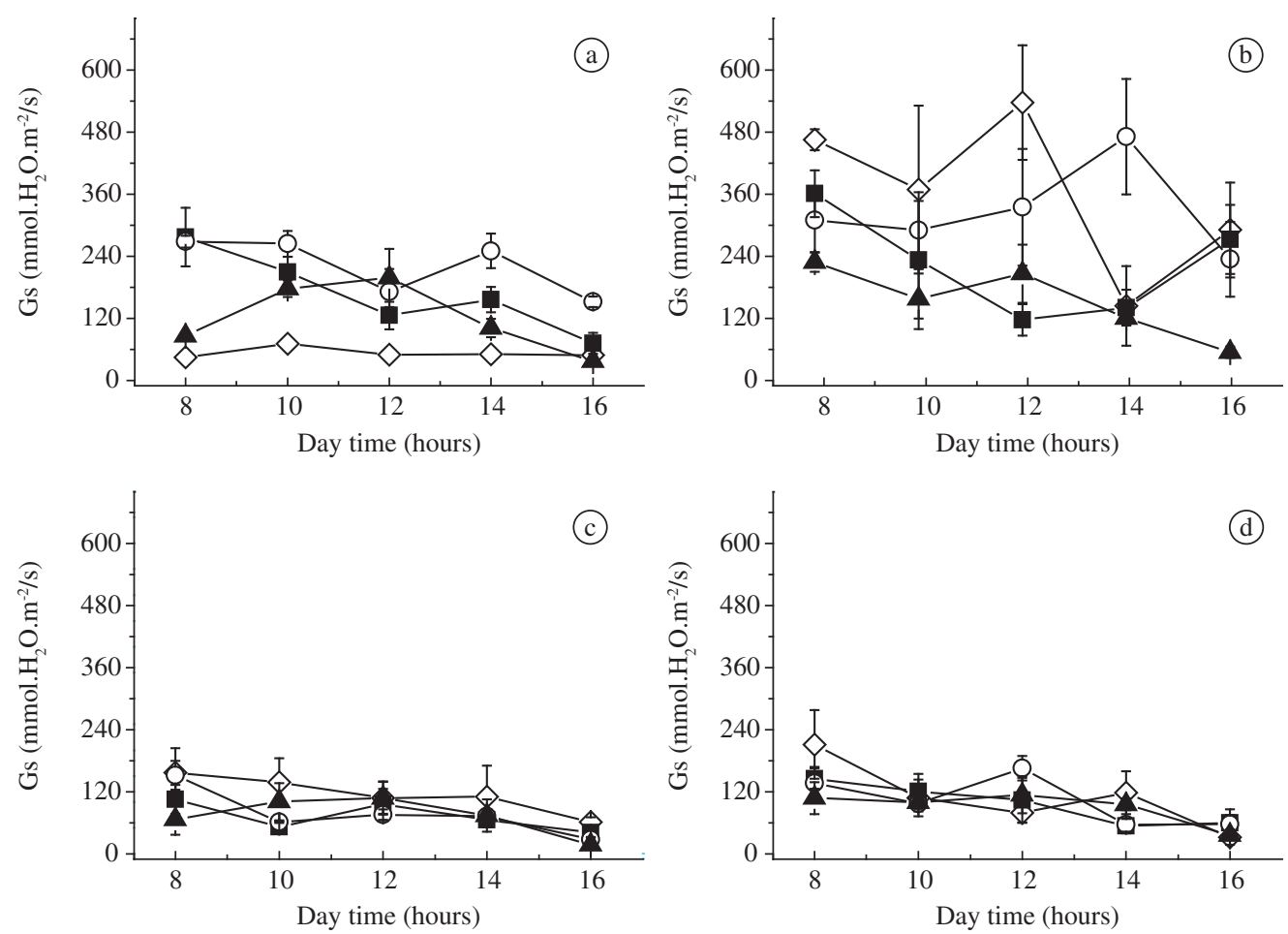

$$
\begin{aligned}
& \longrightarrow \text { Esenbeckia leiocarpa } \longrightarrow \text { Guazuma ulmifolia } \\
& - \text { Hymenaea courbaril } \smile \text { Bauhinia forficata }
\end{aligned}
$$

Figure 4. Diurnal courses of stomatal conductance (gs) in pioneer species Bauhinia forficata and Guazuma ulmifolia (open symbols), and secondary species Hymenaea courbaril and Esenbeckia leiocarpa (solid symbols) grown in a tropical semideciduous forest under gap $(\mathrm{a}, \mathrm{b})$ and understorey $(\mathrm{c}, \mathrm{d})$ conditions. Measurements were taken in May (a, c, dry season, May 2, 2005) and November (b, d, wet season, November 3, 2005) 2005. Symbols are mean values of 3 replicates ( \pm s.e.).

2). In understorey, there were no significant differences in Pri values between functional groups in both months. The same was observed under gap conditions, except for E. leiocarpa that showed lower Pri (Table 1 and 2). In May, Pri was always lower than Rdi in understorey. However, under gap (with exception of E.leiocarpa) Pri was higher than Rdi (Table 1). In November, Pri trended to be higher than $\mathrm{Rd}$ in pioneer species and lower than Rdi in secondary species considering the gap environment. Under low light environment, Pri was consistently lower than Rdi in all species (Table 1 and 2).

In May, gross photosynthesis (Pgi), as a sum of Pni, Rdi and Pri values, was 6- to 12-fold higher in gap than in understorey (Table 1), while in November this difference dropped to two-fold (Table 2). This pattern was observed in all species; however, pioneer exhibited higher Pgi $(\mathrm{P}<0.05)$ than late secondary species under gap conditions. On the other hand, in understorey there were no differences in Pgi between functional groups in both evaluations.

\subsection{Diurnal leaf carbon balance and plant growth}

In May, despite the lower Rdi, relative dark respiration in understorey was consistently higher than under gap. In gap, Rdi ranged from $11 \%$ in B. forficata to $21 \%$ in E. leiocarpa of total assimilated carbon, while in understorey Rdi ranged from $41 \%$ in E. leiocarpa to $78 \%$ in $H$. courbaril (Figure 7). Carbon losses by photorespiration (Pri) did not show such remarkable differences between gap and understorey. The highest difference was observed in E leiocarpa, exhibiting a decrease in Pri percentage in relation to Pgi from gap (19.6\%) to understorey $(11.6 \%)$. On the other hand, diurnal leaf carbon balance in late secondary species was quite stable between gap and understorey in November (Figure 7). In pioneer species, Rdi in understorey was about twice the values observed in gap, while Pr remained similar (Figure 7). This leads to a reduction in Pni percentage in relation to Pgi from gap to understorey (Figure 7). Comparing leaf carbon balance between May and November, respiratory costs in November were higher than in May in 

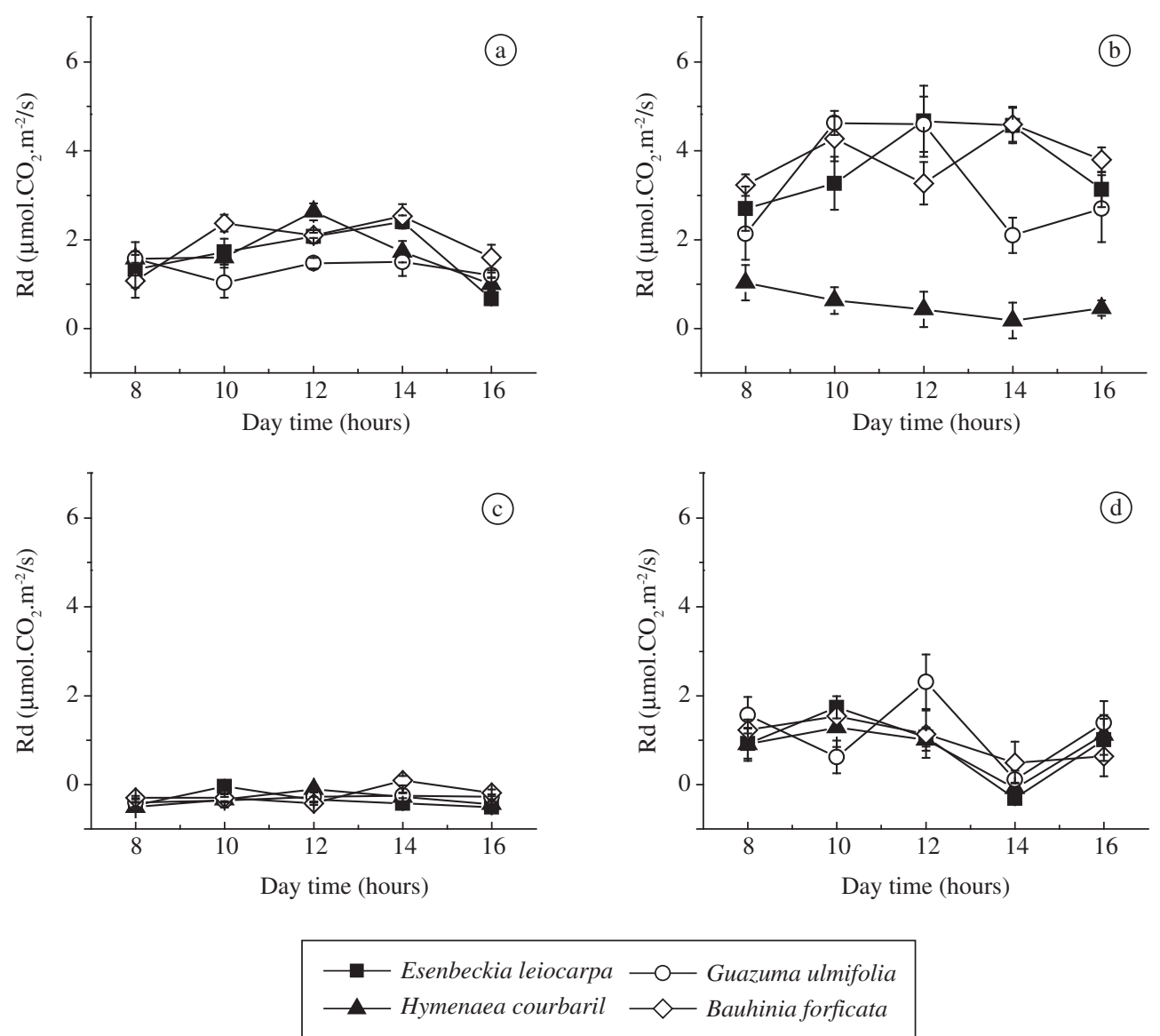

Figure 5. Diurnal courses of dark respiration (Rd) in pioneer species Bauhinia forficata and Guazuma ulmifolia (open symbols), and secondary species Hymenaea courbaril and Esenbeckia leiocarpa (solid symbols) grown in a tropical semideciduous forest under gap (a, b) and understorey (c, d) conditions. Measurements were taken in May (a, c, dry season, May 2, 2005) and November (b, d, wet season, November 3, 2005) 2005. Symbols are mean values of 3 replicates ( \pm s.e.).

all plants grown under gap (Figure 7). The percentage of Pni in relation to Pgi decreased from May to November in all species under gap conditions. However, there was no unique pattern in understorey. In E. leiocarpa, Pni percentage was higher in May than in November, while the opposite was observed in other species, remarkably in $H$. courbaril and G. ulmifolia, due to a drop in Rdi percentage from May to November (Figure 7).

Data on leaf carbon balance must be considered with caution since night leaf respiration was not accounted for, which probably underestimates total leaf carbon cost (Amthor, 2000).

Plant growth patterns supported the differences observed in carbon assimilation between understorey and gap conditions. Primary (height) and secondary (stem diameter) growth from May to November were higher in gap than in understorey for all species. Under gap (Figure 8a), pioneer species showed an increment in stem diameter of $50 \%$ (G. ulmifolia) and $77 \%$ (B. forficata), while in secondary species the corresponding growth was $42 \%$ (E. leiocarpa) and $15 \%$ (H. courbaril). In shade, secondary species exhibited an increment around $12 \%$ in stem diameter, while G. ulmifolia increased $32 \%$ and B. forficata did not grow (Figure 8c). In understorey, increase in plant height was just $5 \%$. However between May and November, in gap conditions, H. courbaril increased its height by around 60\%, E. leiocarpa and G. ulmifolia by around $36 \%$ and B. forficata $48 \%$. Pioneers were consistently taller than secondary species (Figure 8b), also showing higher stem diameter, mainly in November under gap conditions (Figure 8a).

Principal component analysis successfully segregated environments and seasons (Figure 9). PCA analysis was carried out with data from Table 1, 2, and Figure 8 (growth data). The first principal component (pc 1) summarized $72.4 \%$ of original data variation and it was the only principal component retained to explain separation of groups according to the Broken-stick criterion (Peres-Neto et al., 2003). According to eigenvector values (ev), the main physiological parameters that contributed for distinction among species and among environmental conditions were gross photosynthesis $(\mathrm{Pgi}, \mathrm{ev}=0.41$ ) 

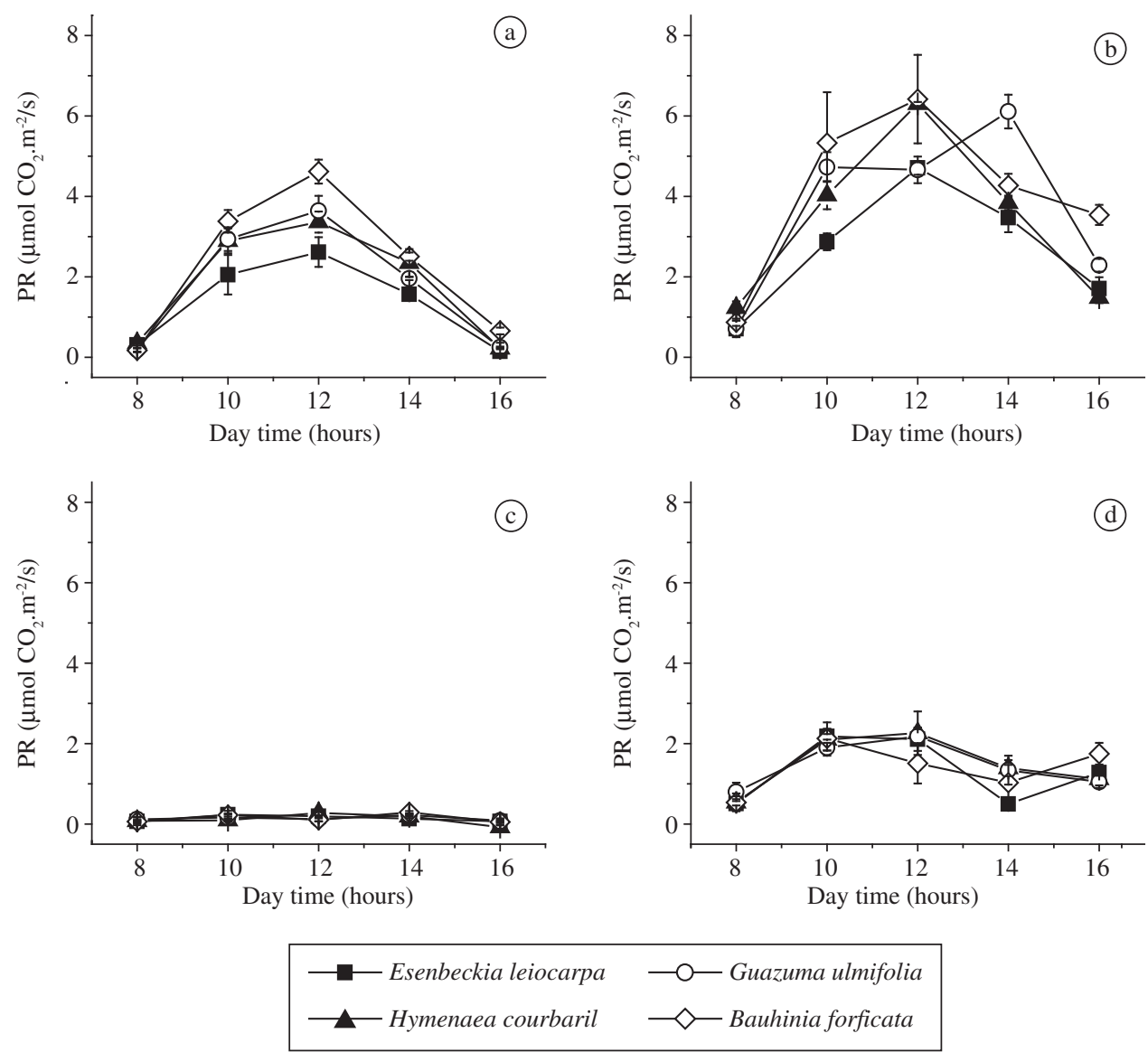

Figure 6. Diurnal courses of photorespiration (Pr) in pioneer species Bauhinia forficata and Guazuma ulmifolia (open symbols), and secondary species Hymenaea courbaril and Esenbeckia leiocarpa (solid symbols) grown in a tropical semideciduous forest under gap (a, b) and understorey (c, d) conditions. Measurements were taken in May (a, c, dry season, May, 2005 ) and November (b, d, wet season, Novermber, 2005) 2005. Symbols are mean values of 3 replicates ( \pm s.e.).

and photorespiration (Pri, ev $=0.41$ ), net photosynthesis $($ Pni, ev $=0.40)$ and transpiration $(\mathrm{Ei}, \mathrm{ev}=0.39)$. The PCA showed that in understorey there was no distinction between functional groups in both months. However, pioneers were quite different from secondary species under gap conditions in November (Figure 9).

\section{Discussion}

Our first hypothesis raised the question whether saplings in understorey conditions would show reduced respiration rates regardless of sucessional status. The results supported this hypothesis. Indeed, higher Rd rates have been reported in high-light and tropical gap environments when compared to low-light and understorey conditions (Bazzaz and Picket, 1980; Chazdon et al., 1996; Feng et al., 2004; Oguchi et al., 2005). In lowlight conditions, low Rd is an essential physiological characteristic to achieve and maintain positive carbon balance (Amthor, 2000; Givnish, 1988). Nevertheless, our results on leaf carbon balance showed that carbon losses, mainly through dark respiration, represent a high carbon cost for plants under shade conditions (Figure 7), even with low Rd values.

Some studies have observed higher Rd values in pioneer rather than in late successional species both in highlight and low-light conditions (Feng et al., 2004; Oguchi et al., 2005). High respiration rates could support the higher growth rates of pioneer species, since respiration provides energy and some intermediate compounds used in plant growth (Azcón-Bieto and Osmond, 1983; Ho and Thornley, 1978). However, Ramos and Grace (1990) and Vera et al. (1999) did not find significant difference in leaf dark respiration between successional groups. In addition, Marenco et al. (2001) observed non-significant differences in $\mathrm{Rd}$ of pioneer and late secondary species in understorey, although under gap conditions $\mathrm{Rd}$ in pioneer have been higher than in late successional species. Considering both evaluations, our results showed that diurnal-integrated dark respiration (Rdi) of late successional was quite similar to pioneer species. Indeed, 


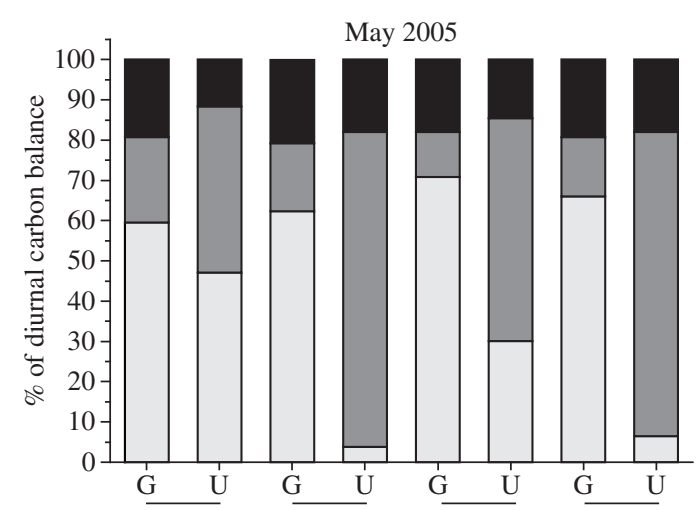

E. leiocarpa H. courbaril B. forficata G. $\overline{\text { ulmifolia }}$ Tree species / forest environments

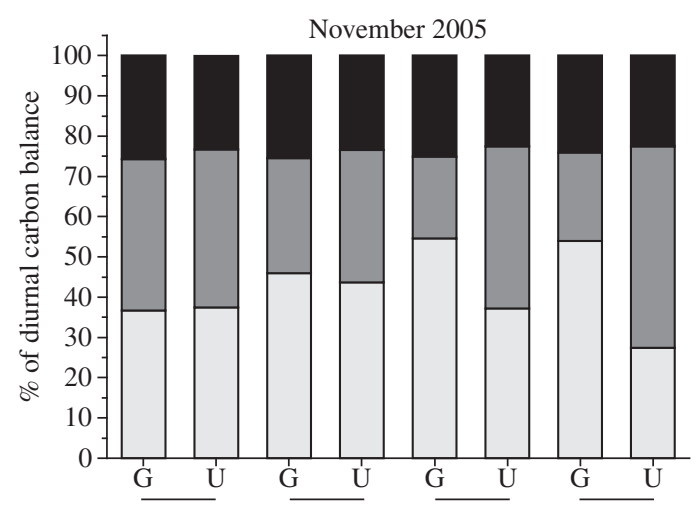

E. leiocarpa H. courbaril B. forficata G. ulmifolia Tree species / forest environments

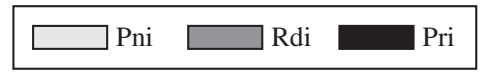

Figure 7. Diurnal leaf carbon balance considering relative diurnal-integrated values of net photosynthesis (Pni), dark respiration (Rdi) and photorespiration (Pri) in relation to the gross photosynthesis in pioneer (Bauhinia forficata and Guazuma ulmifolia) and secondary species (Hymenaea courbaril and Esenbeckia leiocarpa) grown in a tropical semi-deciduous forest under gap (G) and understorey (U) conditions. Measurements were taken in May (dry season) and in November (wet season) 2005.
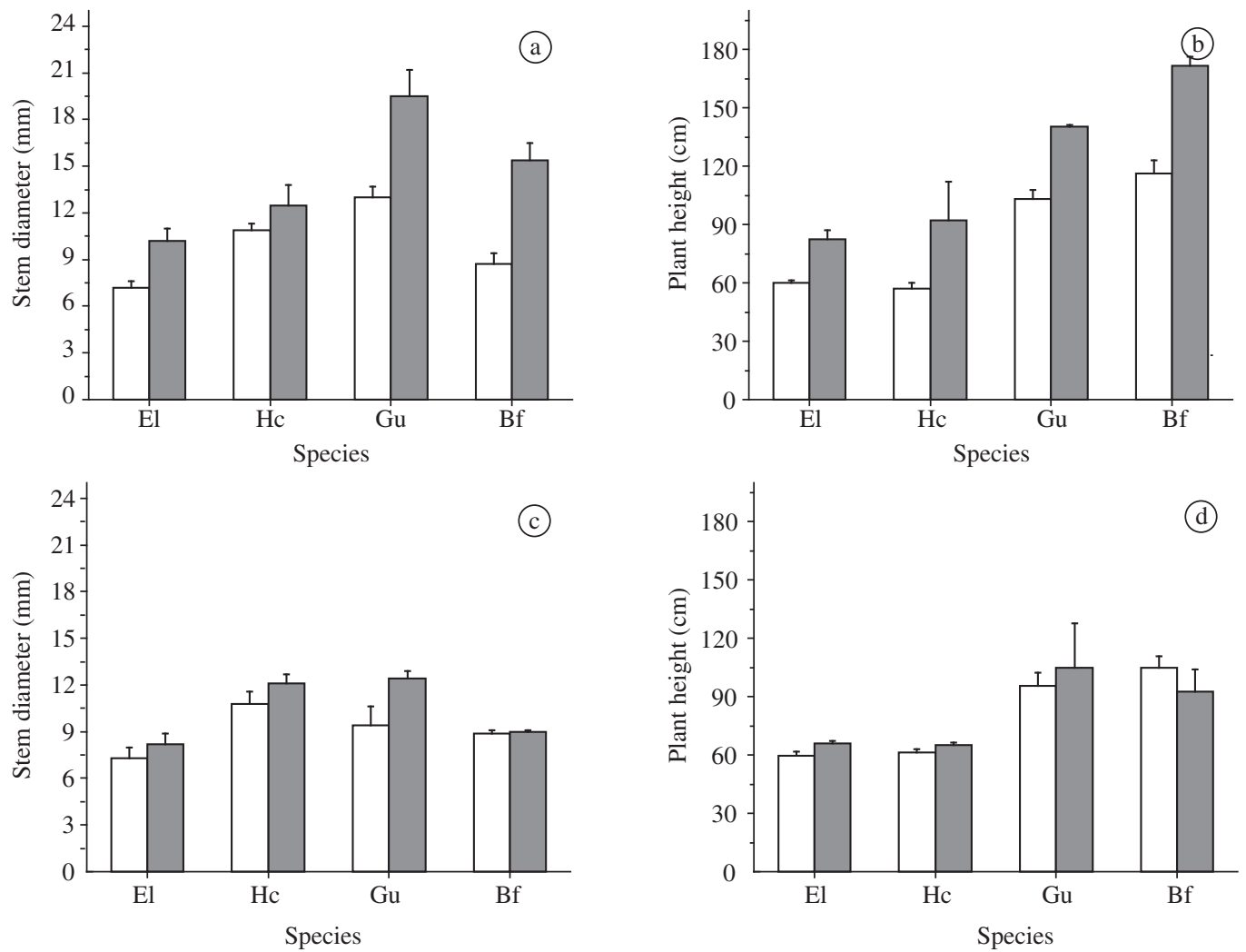

$\square$ May, $2^{\text {nd }} 2005 \square$ November, $3^{\text {rd }} 2005$

Figure 8. Plant height and stem diameter in pioneer (Bauhinia forficata, Bf, and Guazuma ulmifolia, Gu) and secondary species (Hymenaea courbaril, Hc, and Esenbeckia leiocarpa, El) grown in a tropical semi-deciduous forest under gap (a, b) and understorey (c, d) conditions. Measurements were taken in May (dry season) and in November (wet season) 2005. Bars are mean values of 5 replicates (+ s.e.). 


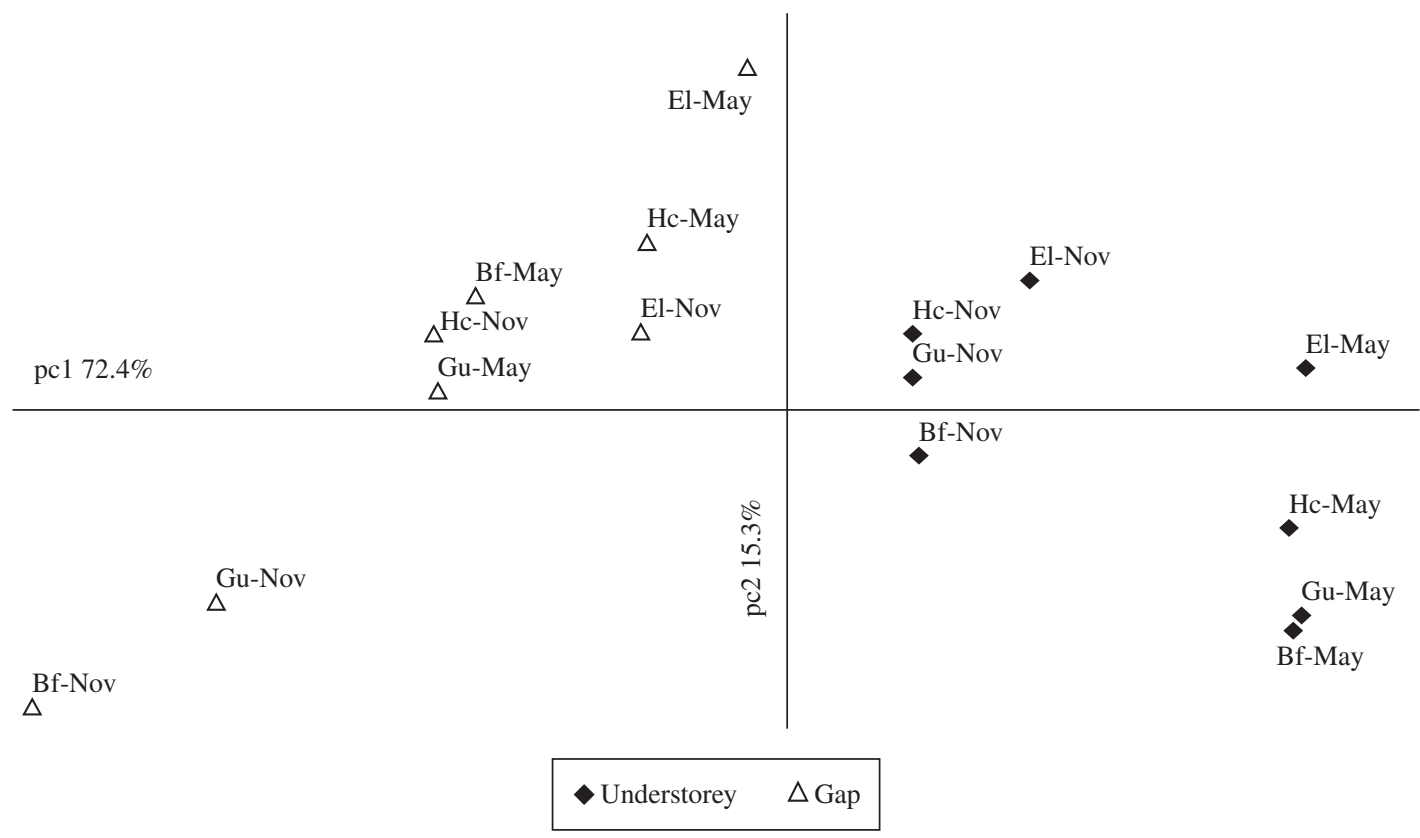

Figure 9. Ordination graph of principal component analysis performed with leaf gas exchange and growth parameters measured in May (dry season) and in November (wet season) 2005. Forest gap environment is indicated by open triangles while understorey is represented by solid diamonds. pc 1, first principal component; pc 2, second principal component. Bf, Bauhinia forficata; Gu, Guazuma ulmifolia; Hc, Hymenaea courbaril; El, Esenbeckia leiocarpa.

G. ulmifolia exhibited lower Rdi than late successional species in May and November (Table 1 and 2). On the other hand, the photorespiration rate of pioneers was often higher than in late secondary species in gap, despite similar contribution of Pr on diurnal leaf carbon balance in all species and environments (Figure 7). High Pr in pioneer species under gap could be an adaptive mechanism of photoprotection, since photorespiration may be an alternative electron sink, reducing excessive energy and preventing damage of photochemical apparatus (Niyogi, 2000). Photorespiration and dark respiration showed similar contribution in diurnal leaf carbon gain regardless of successional status in the gap environment, while dark respiration represented the highest cost in understorey (Figure 7). This is probably related to very low PPFD values (Figure 1a).

The second hypothesis raised in this study was that leaf carbon balance changes during the year due to seasonal variation of environmental conditions, mainly in water availability and temperature. In November, there was an increase in carbon loss by dark respiration and photorespiration in gap (Figure 7), likely due to higher air temperature (Figure 1b). In understorey, relative contribution of Rdi and Pri were higher in May (Figure 7), mainly in H. courbaril and G. ulmifolia (Figure 7) that showed significant reduction of photosynthetic rates when compared to November (Table 1 and 2). However, Pni in gap conditions was quite similar in May and November (Table 1 and 2), despite higher Rdi and Pri in November. Higher net $\mathrm{CO}_{2}$ assimilation in November could be explained by high irradiance availability (Figure 1) and high stomatal conductance (Figure 4). This latter was possible due to a favorable water status, as indicated by $\Psi_{\text {wpd }}$. In November, $\Psi_{\text {wpd }}$ in all species was around - 0.4 MPa regardless of growth environment, while in May those values were around $-1.0 \mathrm{MPa}$. The impact of lower stomatal conductance (Figure 4) in May can be evaluated through the increase in water use efficiency under gap conditions, as a result of low transpiration rates (Table 1).

The third hypothesis that plants growing in highlight environments have higher net $\mathrm{CO}_{2}$ assimilation, respiration and photorespiration rates than those growing in the shade was also supported in all species (Table 1 and 2). Gross photosynthesis (Pgi) under gap conditions was dramatically higher than in understorey in all species, mainly in May (Table 1), when carbon loss due to Rdi and Pri were relatively lower in gap than in understorey (Figure 7). Thus, the positive carbon balance reached in gap was certainly due to a higher efficiency of the photosynthetic apparatus to assimilate atmospheric $\mathrm{CO}_{2}$. In fact, the highest values of maximum net photosynthesis in tropical species are often observed under high-light conditions (Chazdon et al., 1996; Feng et al., 2004; Marenco et al., 2001; Ribeiro et al., 2005; Strauss-Debenedetti and Bazzaz, 1996). Furthermore, leaf nitrogen content is also an important determinant of maximum photosynthetic rates. Leaf nitrogen content tends, on average, to be higher in clearing plants than in understorey plants (Chazdon and Field, 1987; Lee et al. 2005). 
In the classical literature (see Bazzaz, 1979; Bazzaz and Pickett. 1980; Chazdon et al., 1996), pioneer species are considered shade intolerant. However, the results from multivariate analysis taking into account leaf gas exchange and growth parameters failed in showing differences between pioneer and late successional species. In both seasons, there was no segregation among species of different functional groups under shade conditions. The same was observed in May under gap (Figure 9). However, pioneers were distinguished from secondary species in November under gap conditions (Figure 9). This was due to high irradiance and air temperature that could be deleterious to late successional species. It is important to consider that the studied gap was small, with around $10 \%$ of canopy openness. According to Chazdon et al. (1996), the differences between pioneer and secondary species trend to be lower under small gap conditions. However, small gaps in tropical forest are far more frequent than large ones (Martins and Rodrigues, 2002). Considering the tropical forest as a successional mosaic, it is possible that the importance of ecophysiological differences between functional groups have been overestimated when considering the successional pattern in the whole forest. Furthermore, our results suggested that physiological differences between pioneer and late successional species are even less significant in understorey conditions (Figure 9). The results showed herein should be considered carefully since the whole plant carbon balance was not considered, as well as the night $\mathrm{CO}_{2}$ loss by respiration. However, Azcón-Bieto and Osmond (1983) concluded that the rate of night $\mathrm{CO}_{2}$ efflux is comparable to the light $\mathrm{CO}_{2}$ efflux.

Acknowledgements - This study was supported by FAPESP (Fundação de Amparo a Pesquisa do Estado de São Paulo), grant 03/06939-5 and CNPq (Conselho Nacional de Pesquisa e desenvolvimento Tecnológico).

\section{References}

AMTHOR, JS., 2000. The McCree-de Wit-Penning de VriesThornley respiration paradigms: 30 years later. Ann. Bot., vol. 86 , no. 1, p. 1-20.

AZCÓN-BIETO, J. and OSMOND, CB., 1983. Relationship between photosynthesis and respiration. The effect of carbohydrate status on the rate of $\mathrm{CO} 2$ production by respiration in darkened and illuminated wheat leaves. Plant Physiol, vol. 71, no. 3 , p. $574-581$.

BAZZAZ, FA., 1979. Physiological ecology of plant succession. Ann. Rev. Ecol. Syst., vol. 10, p. 351-371.

BAZZAZ, FA. and PICKETT, STA., 1980. Physiological ecology of tropical succession: a comparative review. Ann. Rev. Ecol. Syst., vol. 11, p. 287-310.

CHAZDON, RL. and FIELD, CB., 1987. Determinants of photosynthesis capacity in six rainforest Piper species. Oecologia, vol. 73 , no. 2, p. 222-230.

CHAZDON, RL., PEARCY, RW., LEE, DW. and FETCHER, N., 1996. Photosynthetic responses of tropical forest plants to contrasting light environments. In: Mulkey, SS., Chazdon, RL. and Smith, AP. (Eds.). Tropical forest plant ecophysiology. New York: Chapman \& Hall. p. 5-55.

EMBRAPA - EMPRESA BRASILEIRA DE PESQUISA AGROPECUÁRIA, 2003 [on line]. Banco de Dados Climáticos do Brasil. Available in: <www.bdclima.cnpm.embrapa.br>. Accessed in: Jan 2007.

EAMUS, D., 1999. Ecophysiological traits of deciduous and evergreen woody species in the seasonally dry tropics. TREE, vol. 14, no. 1, p. 11-16.

FARQUHAR, GD. and Von CAEMMERER, S., 1982. Modelling of photosynthetic response to environmental conditions. In: Lange, OL., Nobel, PS., Osmond, CB. and Ziegler, H. (Eds.). Encyclopedia of Plant Physiology. Berlin: Springer-Verlag.

FENG, YL., CAO, KF. and ZHANG, JL., 2004. Photosynthetic characteristics, dark respiration, and leaf mass per unit area in seedlings of four tropical tree species grown under tree irradiance. Photosynthetica, vol. 42, no. 3, p. 431-437.

FREDEEN, AL. and FIELD, CB., 1991. Leaf respiration in Piper species native to a Mexican rainforest. Physiol. Plant., vol. 82 , no. 1 , p. 85-92.

GIVNISH, TJ., 1988. Adaptation to sun and shade: a whole-plant perspective. Aust. J. Plant Physiol., vol. 15, no. 1, p. 63-92.

HO, LC. and THORNLEY, JHM., 1978. Energy requeriments for assimilate translocation from tomato mature leaves. Ann. Bot., vol. 42, no. 2, p. 481-483.

KIKUSAWA, K., SHIRSKAWA, H., SUZUKI, M. and UMEKI, K., 2004. Mean labor time of a leaf. Ecol. Res., vol. 19, no. 4, p. $365-374$

LARCHER, W., 1995. Physiological plant ecology. 3 ed. Berlin: Springer. $506 \mathrm{p}$.

LAVOREL, S., MCINTYRE, S., LANDSBERG, J. and FORBES, TDA., 1997. Plant functional classifications: from general groups to specific groups based on response to disturbance. Trends Ecol. Evol., vol. 12, no. 12, p. 474-478.

LEE, TD., REICH, PB. and BOLSTAD, PV., 2005. Acclimation to leaf respiration to temperature is rapid and related to specific leaf area, soluble sugars and leaf nitrogen across three temperate deciduous tree species. Funct. Ecol., vol. 19, no. 4, p. 640-647.

LORENZI, H., 1992. Árvores brasileiras: manual de identificação e cultivo de plantas arbóreas nativas do Brasil. Nova Odessa: Plantarum. 352 p.

MARENCO, RA., GONÇALVES, JFC. and VIEIRA, G., 2001. Leaf gas Exchange and carbohydrates in tropical trees differing in successional status in two light environments in central Amazônia. Tree Physiol., vol. 21, no. 18, p. 1311-1318

MARTINS, SV. and RODRIGUES, RR., 2002. Gap-phase regeneration in a semideciduous mesophytic Forest, south-

eastern Brazil. Plant Ecol., vol. 163, no. 12, p. 51-62.

MIRANDA, EJ., VOURLITIS, GL., PRIANTE-FILHO, N., PRIANTE, PC., CAMPELO Jr., JH., SULI, GS., FRITZEN, CL., LOBO, FA. and SHIRAIWA, S., 2005. Seasonal variation in the leaf gas exchange of tropical forest trees in the rainsavanna transition of the southern Amazon basin. J. Trop. Ecol., vol. 21, p. 451-460. DOI: 10.1017/S0266467405002427

NIYOGI, KK., 2000. Safety valves for photosynthesis. Curr. Op. Plant Biol., vol. 3, no. 6, p. 455-460. 
OGUCHI, R., HIKOSAKA, K. and HIROSE, T., 2005. Leaf anatomy as a constraint for photosynthetic acclimation: differential responses in leaf anatomy to increasing growth irradiance among three deciduous trees. Plant Cell Environ., vol. 28 , no. 7 , p. $916-927$.

PERES-NETO, PR., JACKSON, DA. and SOMERS, KM., 2003. Giving meaningful interpretation to ordination axes: assessing loading significance in principal component analysis. Ecology, vol. 84, no. 9, p. 2347-2363.

PRADO, CHBA., WENHUI, Z., ROJAS, MHC. and SOUZA, GM., 2004. Seasonal leaf gas exchange and water potential in a cerrado woody species community. Braz. J. Plant Physiol., vol. 16 , no. 1 , p. $7-16$.

RAMOS, J. and GRACE, J., 1990. The effects of shade on the gas exchange of seedlings of four tropical trees from Mexico. Funct. Ecol., vol. 4, no. 5, p. 667-677.

REICH, PB., WALTERS, MB., TJOELKER, MG., VANDERKLEIN, D. and BUSCHENA, C., 1998. Photosynthesis and respiration rates depend on leaf and root morphology and nitrogen concentration in nine boreal tree species differing in relative growth rate. Funct. Ecol., vol. 12, no. 3, p. 395-405.

RIBEIRO, RV., SOUZA, GM., MANZATTO, AG., MACHADO, EC. and OLIVEIRA, RF., 2004. Chlorophyll fluorescence of tropical tree species in a semi-deciduous forest gap. Rev. Árv., vol. 28 , no. 1 , p. 21-27.

RIBEIRO, RV., SOUZA, GM., OLIVEIRA, RF. and MACHADO, EC., 2005. Photosynthetic responses of tropical tree species from different successional groups under contrasting irradiance conditions. Rev. Bras. Bot., vol. 28, no. 1, p. 149-161.

SHARKEY, TD., 1988. Estimating the rate of photorespiration in leaves. Physiol. Plant., vol. 73, no. 1, p. 147-152.

SOUZA, GM., RIBEIRO, RV., SANTOS, MG., RIBEIRO, HL. and OLIVEIRA, RF., 2004. Functional groups of forest succession as dissipative structures: an applied study. Braz. $J$. Biol., vol. 64, no. 3b, p. 707-718.

STRAUSS-DEBENEDETTI, S. and BAZZAZ, FA., 1996. Photosynthetic characteristics of tropical trees along successional gradients. In: Mulkey, SS., Chazdon, RL. and Smith, AP. (Eds.). Tropical forest plant ecophysiology. New York: Chapman \& Hall. p. 162-186

THORNTHWAITE, CW. and MATHER, JR., 1955. The water balance. Publications in Climatology. New Jersey: Drexel Institute of Technology. $104 \mathrm{p}$.

VALLADARES, F., WRINGHT, SJ., LASSO, E., KITAJIMA, K. and PEARCY, RW., 2000. Plastic Phenotypic response to light of 16 congenetic shrubs from a panamanian rainforest. Ecology, vol. 81, no. 7, p. 1925-1936.

VERA, NE., FINEGAN, B. and NEWTON, AC., 1999. The photosynthetic characteristics of saplings of eight canopy tree species in a disturbed neotropical rain Forest. Photosynthetica, vol. 36, no. 3, p. 407-422.

WRIGHT, IJ., REICH, PB., ATKIN, OK., LUSK, CH., TJOELKER, MG. and WESTOBY, M., 2005. Irradiance, temperature and rainfall influence leaf dark respiration in woody plants: evidence from comparisons across 20 sites. New Phytol. DOI 10.1111/j.1469-8137.2005. 